\title{
Medicinal Plants Used to Treat Oral Diseases in the Lepelle- Nkumpi Municipality, Limpopo Province, South Africa
}

\author{
Sebua Silas Semenya ${ }^{1}$, Sekgothe Mokgoatšana ${ }^{2}$ and Alfred Maroyi ${ }^{3,{ }^{*}}$ \\ ${ }^{1}$ Technology Transfer Office, Research Administration and Development Department, University of Limpopo, \\ Private Bag X1106, Sovenga 0727, South Africa \\ ${ }^{2}$ Department of Cultural and Political Studies, University of Limpopo, Private Bag X1106, Sovenga 0727 , \\ South Africa \\ ${ }^{3}$ Medicinal Plants and Economic Development (MPED) Research Centre, Department of Botany, University of \\ Fort Hare, Private Bag X1314, Alice 5700, South Africa \\ ${ }^{4}$ Department of Biodiversity, University of Limpopo, Private Bag X1106, Sovenga 0727, South Africa
}

\begin{abstract}
Purpose: Therefore, this study was aimed at documenting medicinal plants used to treat oral diseases in the Lepelle-Nkumpi Municipality in the Limpopo Province, South Africa.

Methods: Data was collected using a semi-structured questionnaire, supplemented by field observations with 30 traditional healers from the Lepelle-Nkumpi Municipality in the Capricorn District of the Limpopo Province in South Africa.

Results: A total of 41 plant species belonging to 30 botanical families, mainly the Asteraceae and Solanaceae $(13.3 \%$ each), were reported as remedies for different oral diseases. Leaves $(51 \%)$ and roots $(28 \%)$, harvested from herbs and trees were preferred for medicinal preparations. The majority of plant species $(60.4 \%)$ were used as monotherapy, to treat a single oral disease, while the remainder (39.6\%) treated more than one ailment. The majority of the species $(44.2 \%)$ were used as herbal medicines for toothache, followed by $32.6 \%$ used against bad breath and $25.6 \%$ used against dental caries.

Conclusion: Traditional healers play an important role in the provision of primary health care as oral pathogens are also responsible for nonstomatological infections.
\end{abstract}

Keywords: Medicinal plants, Limpopo Province, oral diseases, South Africa.

\section{INTRODUCTION}

Oral health is a state of being free from benign tumors, cancrum oris, chronic periodontal (gum) disease, chronic mouth and facial pain, congenital abnormalities, dental caries (tooth decay), edentulism, facial trauma, fluorosis, malocclusion, oral cancer, oral manifestation of human immunodeficiency virus/ acquired immunodeficiency syndrome (HIVIAIDS), oral sores, tooth loss and disorders that affect the oral cavity [1]. Thus, any individual who is diagnosed with one or a combination of these conditions is said to suffer from oral disease/s. The $2010 \mathrm{Global}$ Burden of Diseases, Injuries and Risk Factors Study estimated that most of the aforesaid oral conditions affected 3.9 billion people, with an increased burden of $21 \%$ between 1990 and 2010 [2]. Although not often lifethreatening, oral diseases represent a major public health problem, primarily because of their high prevalence and significant impact on general

${ }^{*}$ Address correspondence to this author at the Medicinal Plants and Economic Development (MPED) Research Centre, Department of Botany, University of Fort Hare, Private Bag X1314, Alice 5700, South Africa; Tel: +27719600326; Fax: +27866177642; E-mail: amaroyi@ufh.ac.za health [3]. For example, people that have lost their teeth tend to avoid food that requires mastication, and this avoidance leads to inadequate nutritional intake [4]. There are several psychological problems associated with having discoloured, diseased or missing teeth, namely the victim becomes uncomfortable socializing, loses self-esteem and begins a spiral of decline [5]. Oral diseases are more common in developing countries than in industrialized countries. In several African countries for example, most of these diseases are widespread among low socio-economic status and poor communities residing in rural and marginalized areas [6]. According to the World Health Organisation [1], millions of African populations with a low socio-economic status are affected by oral disease. Indeed, studies conducted in various African countries support this. For instance, in a national survey conducted in Nigeria, the prevalence of dental carries was $30 \%$ and $43 \%$ amongst the citizens aged 12 and 15 years, respectively [7]. Another study conducted in Nigeria reported gingivitis and periodontitis in $75.4 \%$ and $15.4 \%$, respectively in an adult male population [8]. Muwazi et al. [9] found that $61 \%$ of both children and adults in Uganda suffer from 
malocclusion. Recently, the Namibian national oral health survey reported the gingivitis-calculus complex as the most common periodontal condition (44.1\%) amongst the 15-year-old children [10]. In a Kenyan national survey, the prevalence of dental caries among children aged 5, 12 and 15 year olds was 23.9\%, bleeding the gums and dental fluorosis occurred in $75.7 \%$ and $41.7 \%$, respectively in these children [11]. Approximately $47 \%$ and $12 \%$ of the Tanzanian population was affected by salivary gland disease and xerostomia, and oral candidosis, respectively in the year 2000 [12]. Oral diseases are also one of the major health burdens in South Africa [13]. For example, the prevalence of dental caries in Mpumalanga, Gauteng, Limpopo and Kwa-Zulu Natal provinces was found to be $87.9 \%, 85.1 \%, 58.7 \%$ and $30.6 \%$, respectively [14]. The incidence of periodontal diseases (calculus) in 15 and 35 to 44 old South African was found to be $59.9 \%$ and $66.9 \%$, respectively [15]. Same authors found that from all adults in South Africa in the age group of 35 to 34 years, $12.6 \%$ were totally edentulous. South Africa's high burden of oral diseases is attributed to multiple factors which include amongst others, low dentist to population ratio $(1: 150000)$ and restriction of oral health services to central hospitals or urban areas [8], lack of access to clean water and poor oral hygiene [16], and antibiotic resistance in microorganisms causing oral infections $[17,18]$. In addition to the listed factors, several microorganisms such as Aggregatibacter actinomycetemcomitans, Eikenella corredens, Fusobacterium nucleatum, Lactobacillus acidophilus, Porphyromonas gingivalis, Prevotella intermedia, Staphylococcus aureus, Streptococcus mutans, Streptococcus sobrinus, Tannerella forsythia, Treponema denticola Candida albicans and Tannerella forsythus $[17,19]$ are known to be responsible for oral diseases.

Most oral diseases can largely be prevented through simple, cost-effective measures that involve reducing exposure to recognized risks and strengthening healthy behaviours. Other preventive measures address risk factors for oral disease namely unhealthy diet (in particular high sugar intake), tobacco use, alcohol consumption, and a set of broader health determinants [20]. The phytochemicals possessed by plants have been considered as good alternatives in the management and treatment of various oral diseases [21-24]. Hence, traditional medicines are utilized to treat manage oral diseases in several African countries [25-27]. Despite this, few ethnobotanical studies have been conducted to document medicinal plants used by indigenous people in Africa to treat oral diseases. These studies have been conducted in Tanzania [28], Burkina Faso [29], Nigeria [30], Cameroon [31,32] and Kenya [18]. However, in South Africa there is dearth of information on medical plants used to manage oral diseases. Therefore, this study was aimed at documenting medicinal plants used to treat oral diseases in the Lepelle-Nkumpi Municipality in the Limpopo Province, South Africa.

\section{MATERIALS AND METHODS}

\section{Study Area}

The study was carried out in Ga-Mphahlele village situated in the Lepelle-Nkumpi Municipality (Figure 1). This municipality is one of five within the Capricorn district in the Limpopo Province, and it is situated in the southern part of this district in a mountainous area of the Drakensberg [33]. The study area falls within a subtropical climate with very hot, humid summers and a cooler, dry and sunny winter season. The average annual rainfall is $489 \mathrm{~mm}$, with most of the rain falling between the months of October and March with the peak period being December or January [33]. The vegetation type of the study area was described as the Poung Dolomote Mountain Bushveld by Mucina and Rutherford [34]. The dominant tree species comprises of Boscia albitrunca (Burch.) Gilg \& Gilg-Ben., Combretum hereroense Schinz, Croton gratissimus Burch., Dombeya autumnalis I.Verd, Hippobromus paucifloru (L.f.) Radlk. and Kirkia wilmsii Engl. The municipality is pre-dominantly rural with a population of approximately 230350 people [35], and it covers a total area of $3,454.78 \mathrm{~km}^{2}$. About $95 \%$ of its land falls under the jurisdiction of traditional authorities [33]. Majority of people in the studied area belonging to the Bapedi ethnic group, who constitute about $86 \%$ of the entire populations [36].

\section{Collection of Ethnobotanical Data}

A pilot study was conducted in the study area and local tribal leaders were approached requesting permission to conduct ethnobotanical survey within the area of their jurisdiction, and to recruit traditional healers to take part in this survey. The objective of the study was shared with traditional healers and all conversations were done in Sepedi, the local language. Data was collected between February and September 2017 using a structured questionnaire with 30 traditional healers who agreed to take part in the study. Questionnaires were designed to obtain data on the plant species used to treat different oral ailments, availability status of the plants, methods of herbal 


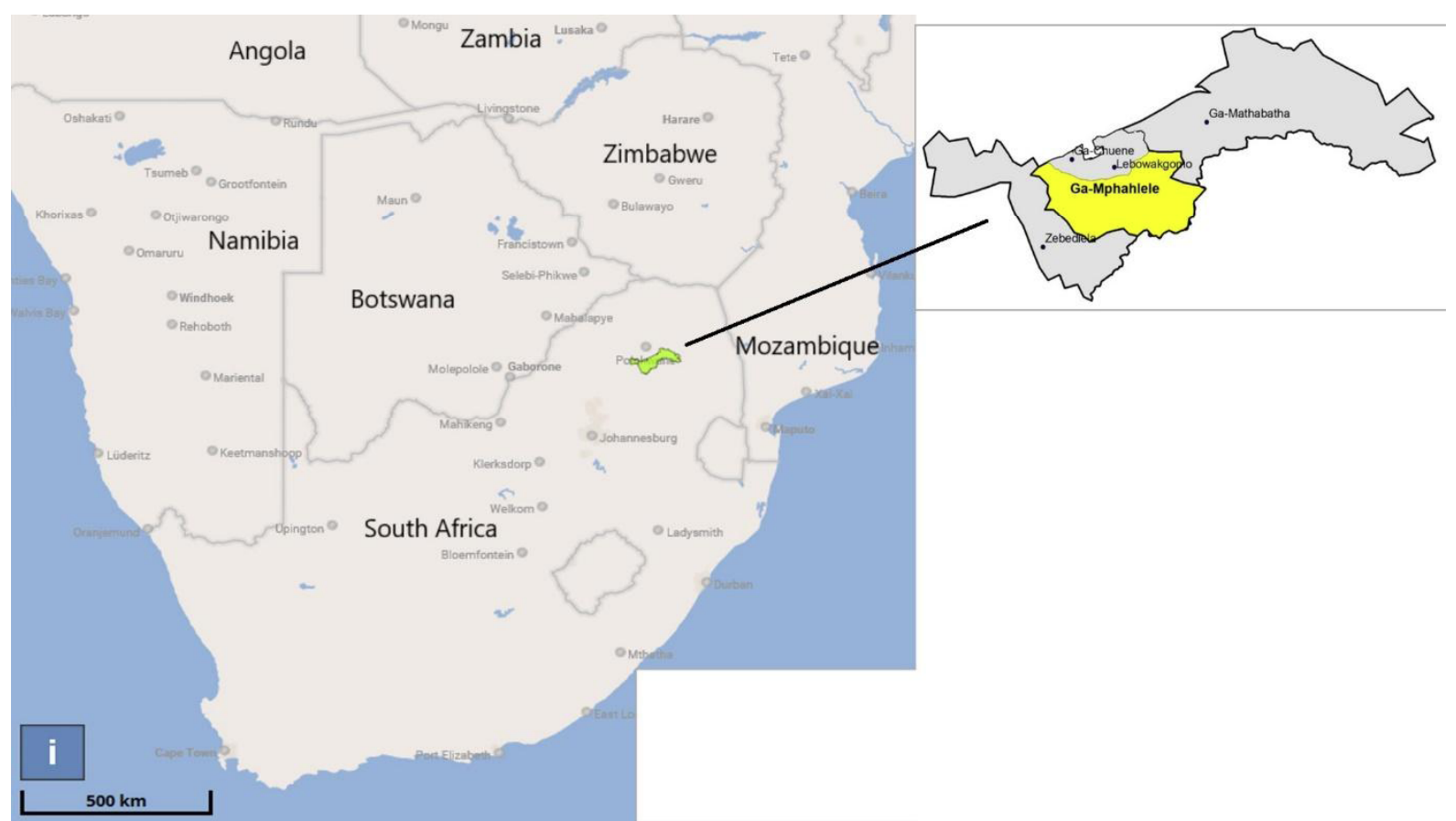

Figure 1: Map of southern Africa showing the Lepelle-Nkumpi Municipality and Ga-Mphahlele village, the study area.

preparation and dosage. Field trips were arranged with each healer to collect the plant specimens of medicinal plants mentioned during the interview sessions. The collected specimens were pressed, dried and mounted on herbarium sheets for the identification by a trained taxonomist.

\section{Data Analysis}

Information obtained in this study were analysed using Microsoft Excel and summarized using descriptive statistics such as frequencies and percentages.

\section{RESULTS AND DISCUSSION}

\section{Diversity of Medicinal Plants}

A total of 41 species (20 exotics and 21 native) distributed in 40 genera, belonging to 30 botanical families were reported as medicinal for different oral diseases (Table 1). Plant families with the highest number of species were Asteraceae and Solanaceae represented by four species each (13.3\%), followed by Euphorbiaceae with three species (10\%). The remaining plant families were represented by less than three taxa each. Asteraceae and Solanaceae are consistently reported by different researchers as being the most important families in the treatment of oral ailments. For instance, both these families were best presented in a study conducted in Nairobi County in Kenya [18]. Asteraceae was also the most used botanical families in the treatment of oral diseases in Kampala in Uganda [37].

The majority of species $(60.4 \%, n=26)$ were used to treat and manage a single oral disease, and the rest of the species $(39.5 \%, n=17)$ were used to manage more than one ailment (Table 1). Contrary to our findings, Tapsoba and Deschamps [29] and Idu et al. [30] found that many species in their surveys were used to manage diverse oral diseases in Burkina Faso and Nigeria, respectively. The majority of the species $(44.2 \%)$ were used as herbal medicines for toothache, followed by $32.6 \%$ used against bad breath and $25.6 \%$ used against dental caries. The remaining oral diseases/conditions namely strengthening of teeth $(n=6$ spp.), bleeding gums ( $n=3$ spp.), swollen gums $(n=2$ spp.), dental abscess, gum boils, mouth ulcer, oral cancer, tooth sensitivity and whiten tooth $(n=1 \mathrm{spp}$., for each) were treated with a smaller proportion of species (Table 1). This finding might be an indication that interviewees have limited knowledge about the plants that can be used to treat or manage the ailments or these ailments are not a serious problem in the study area.

\section{Inventory of Selected Plant Species}

The following species were widely used in the study area and were mentioned by all participants (Table 1 ): Artemisia afra (bad breath), Cannabis sativa (bad breath and dental caries), Carpobrotus edulis (toothache), Mentha longifolia (bad breath), Nicotiana 
Table 1: Plants Used to Treat Oral Diseases in Lepelle-Nkumpi Municipality in the Limpopo Province, South Africa. Species Marked with an Asterisk (*) are Exotic to South Africa

\begin{tabular}{|c|c|c|c|c|}
\hline Species and family name & $\begin{array}{l}\text { Used } \\
\text { part/s }\end{array}$ & Methods of preparation, administration and dosage & $\begin{array}{l}\text { Oral } \\
\text { ailment/s } \\
\text { treated }\end{array}$ & $\begin{array}{l}\text { Frequency } \\
\qquad(\%)\end{array}$ \\
\hline $\begin{array}{l}\text { Artemisia afra Jacq. ex Willd. var. } \\
\text { afra, Asteraceae }\end{array}$ & Leaves & Chewed thrice a day & Bad breath & 100 \\
\hline \multirow[t]{2}{*}{ "Cannabis sativa L., Cannabaceae } & \multirow[t]{2}{*}{ Leaves } & \multirow{2}{*}{$\begin{array}{l}\text { Boiled for 5-30 minutes and extracts used as mouth } \\
\text { wash thrice a day }\end{array}$} & Bad breath & 100 \\
\hline & & & Dental caries & 53.3 \\
\hline \multirow{2}{*}{$\begin{array}{l}\text { Carpobrotus edulis (L.) L.Bolus } \\
\text { subsp. edulis, } \\
\text { Mesembryanthemaceae }\end{array}$} & \multirow[t]{2}{*}{ Leaves } & Chewed as raw and taken thrice a day & Toothache & 100 \\
\hline & & $\begin{array}{c}\text { Boiled for } 5 \text { minutes and extract used as mouth wash } \\
\text { thrice a day }\end{array}$ & Dental caries & 3.3 \\
\hline Mentha longifolia L., Lamiaceae & Leaves & Chewed as raw. Thrice a day & Bad breath & 100 \\
\hline "Nicotiana tabacum L., Solanaceae & Leaves & $\begin{array}{l}\text { Pounded and one teaspoon applied on teeth cavity } \\
\text { thrice a day }\end{array}$ & Toothache & 100 \\
\hline "Punica granatum L., Punicaceae & Roots & $\begin{array}{l}\text { Boiled for 5-12 minutes and extract used as mouth } \\
\text { wash thrice a day }\end{array}$ & $\begin{array}{l}\text { Bleeding } \\
\text { gums }\end{array}$ & 100 \\
\hline $\begin{array}{l}\text { "Ricinus communis L., } \\
\text { Euphorbiaceae }\end{array}$ & Leaves & $\begin{array}{l}\text { Boiled for 5-10 minutes and extracts used as mouth } \\
\text { wash thrice a day }\end{array}$ & Toothache & 100 \\
\hline \multirow{2}{*}{$\begin{array}{l}\text { Solanum panduriforme E.Mey., } \\
\text { Solanaceae }\end{array}$} & Seeds & Burned and smoke inhaled thrice a day & Dental caries & 100 \\
\hline & Roots & $\begin{array}{l}\text { Boiled for 5-17 minutes. Extracts used as mouth wash. } \\
\text { Thrice a day }\end{array}$ & Toothache & 100 \\
\hline \multirow[t]{2}{*}{$\begin{array}{l}\text { Zanthoxylum capense (Thunb.) } \\
\text { Harv., Rutaceae }\end{array}$} & \multirow[t]{2}{*}{ Roots } & $\begin{array}{l}\text { Boiled for 7-10 minutes and extract used as mouth } \\
\text { wash thrice a day }\end{array}$ & Toothache & 100 \\
\hline & & Chewed as raw thrice a day & Bad breath & 50 \\
\hline \multirow[t]{2}{*}{$\begin{array}{l}\text { Ziziphus mucronata Willd. subsp. } \\
\text { mucronata, Rhamnaceae }\end{array}$} & \multirow[t]{2}{*}{ Roots } & $\begin{array}{l}\text { Boiled for 5-14 minutes and extract used as mouth } \\
\text { wash thrice a day }\end{array}$ & \multirow[t]{2}{*}{ Toothache } & 100 \\
\hline & & $\begin{array}{l}\text { Pounded and one teaspoon of extract applied on teeth } \\
\text { thrice a day }\end{array}$ & & 100 \\
\hline $\begin{array}{l}\text { Agave americana L., } \\
\text { Asparagaceae }\end{array}$ & Leaves & $\begin{array}{l}\text { Macerated in warm water for } 5-24 \text { hours and used as } \\
\text { mouth wash }\end{array}$ & Toothache & 90 \\
\hline "Allium sativum L., Amaryllidaceae & Bulb & $\begin{array}{l}\text { Boiled for 7-12 minutes and extract used as mouth } \\
\text { wash thrice a day }\end{array}$ & Toothache & 76.6 \\
\hline $\begin{array}{l}\text { Vernonia natalensis Sch.Bip. ex } \\
\text { Walp, Asteraceae }\end{array}$ & Roots & $\begin{array}{l}\text { Boiled for 6-19 minutes and extract used as a mouth } \\
\text { wash thrice a day }\end{array}$ & Bad breath & 73.3 \\
\hline \multirow{2}{*}{$\begin{array}{l}\text { "Zingiber officinale Roscoe, } \\
\text { Zingiberaceae }\end{array}$} & \multirow[t]{2}{*}{ Rhizome } & \multirow{2}{*}{$\begin{array}{l}\text { Boiled for 5-13 minutes and extracts used as mouth } \\
\text { wash thrice a day }\end{array}$} & Bad breath & 63.3 \\
\hline & & & Dental caries & 6.6 \\
\hline \multirow[t]{2}{*}{$\begin{array}{l}\text { Solanum mauritianum Scop., } \\
\text { Solanaceae }\end{array}$} & \multirow[t]{2}{*}{ Seeds } & \multirow[t]{2}{*}{$\begin{array}{l}\text { Macerated in warm water for } 24 \text { hours and decoction } \\
\text { used as mouth wash thrice a day }\end{array}$} & $\begin{array}{l}\text { Strengthen } \\
\text { teeth }\end{array}$ & 50 \\
\hline & & & Dental caries & 60 \\
\hline $\begin{array}{l}\text { Siphonochilus aethiopicus } \\
\text { (Schweinf.) B.L.Burtt., } \\
\text { Zingiberaceae }\end{array}$ & Rhizome & Chewed as raw thrice a day & Bad breath & 46.6 \\
\hline $\begin{array}{l}\text { Acacia senegal (L.) Willd., } \\
\text { Fabaceae }\end{array}$ & Roots & $\begin{array}{l}\text { Boiled for 8-17 minutes and extract used as mouth } \\
\text { wash thrice a day }\end{array}$ & Dental caries & 40 \\
\hline *Aloe vera Mill., Asphodelaceae & Leaves & Chewed and used as mouth wash thrice a day & Toothache & 40 \\
\hline \multirow[t]{2}{*}{ "Carica papaya L., Caricaceae } & \multirow[t]{2}{*}{ Leaves } & $\begin{array}{l}\text { Crushed and mixed with salt } \circledast \text { and mixture applied on } \\
\text { painful teeth }\end{array}$ & $\begin{array}{l}\text { Dental } \\
\text { abscess }\end{array}$ & 40 \\
\hline & & $\begin{array}{l}\text { Boiled for } 5 \text { minutes and extract used as mouth wash } \\
\text { thrice a day }\end{array}$ & Toothache & 3.3 \\
\hline \multirow{2}{*}{$\begin{array}{l}\text { Securidaca longepedunculata } \\
\text { Fresen. var. longepedunculata, } \\
\text { Polygalaceae }\end{array}$} & \multirow[t]{2}{*}{ Roots } & \multirow{2}{*}{$\begin{array}{l}\text { Mixed with leaves of } N \text {. tabacum in warm water and } \\
\text { mixture taken orally as mouth wash thrice a day }\end{array}$} & Bad breath & 36.6 \\
\hline & & & $\begin{array}{l}\text { Bleeding } \\
\text { gums }\end{array}$ & 3.3 \\
\hline \multirow{2}{*}{$\begin{array}{l}\text { Dodonaea viscosa Jacq. Var. } \\
\text { angustifolia (L.F.) Benth., } \\
\text { Sapindaceae }\end{array}$} & \multirow[t]{2}{*}{ Leaves } & \multirow{2}{*}{$\begin{array}{l}\text { Boiled for 5-10 minutes and extracts used as mouth } \\
\text { wash thrice a day }\end{array}$} & Bad breath & 36.6 \\
\hline & & & Dental caries & 16.6 \\
\hline
\end{tabular}


(Table 1). Continued.

\begin{tabular}{|c|c|c|c|c|}
\hline Species and family name & $\begin{array}{l}\text { Used } \\
\text { part/s }\end{array}$ & Methods of preparation, administration and dosage & $\begin{array}{l}\text { Oral } \\
\text { ailment/s } \\
\text { treated }\end{array}$ & $\begin{array}{l}\text { Frequency } \\
\text { (\%) }\end{array}$ \\
\hline \multirow{3}{*}{$\begin{array}{l}\text { "Senna didymobotrya (Fresen.) } \\
\text { Irwin \& Barneby, Fabaceae }\end{array}$} & \multirow[t]{3}{*}{ Roots } & \multirow{3}{*}{$\begin{array}{l}\text { Boiled for 4-10 minutes and extract used as mouthwash } \\
\text { thrice a day }\end{array}$} & Toothache & 33.3 \\
\hline & & & $\begin{array}{l}\text { Dental } \\
\text { caries }\end{array}$ & 16.6 \\
\hline & & & Mouth ulcer & 3.3 \\
\hline \multirow{3}{*}{$\begin{array}{l}\text { Euphorbia ingens E.Mey. ex Boiss., } \\
\text { Euphorbiaceae }\end{array}$} & \multirow[t]{3}{*}{ Stem } & \multirow[t]{3}{*}{ Squeezed and sap used as mouth wash thrice a day } & Bad breath & 26.6 \\
\hline & & & $\begin{array}{l}\text { Bleeding } \\
\text { gums }\end{array}$ & 10 \\
\hline & & & Whiten teeth & 33.3 \\
\hline \multirow{2}{*}{ Kleinia longiflora DC, Asteraceae } & \multirow[t]{2}{*}{ Leaves } & \multirow{2}{*}{$\begin{array}{l}\text { Boiled for 10-20 minutes and extract used as mouth } \\
\text { wash thrice a day }\end{array}$} & Gum boils & 26.6 \\
\hline & & & $\begin{array}{l}\text { Swollen } \\
\text { gums }\end{array}$ & 3.3 \\
\hline \multirow{2}{*}{ *Bidens pilosa L., Asteraceae } & \multirow[t]{2}{*}{ Leaves } & \multirow{2}{*}{$\begin{array}{c}\text { Macerated in warm water for } 5-30 \text { hours and used as } \\
\text { mouth wash thrice a day }\end{array}$} & Toothache & 16.6 \\
\hline & & & Bad breath & 3.3 \\
\hline $\begin{array}{l}\text { Withania somnifera (L.) Dunal., } \\
\text { Solanaceae }\end{array}$ & Roots & $\begin{array}{l}\text { Boiled for } 5 \text { minutes and extract used as mouth wash } \\
\text { thrice a day }\end{array}$ & Bad breath & 16.6 \\
\hline \multirow{2}{*}{$\begin{array}{l}\text { Ximenia americana L. var. } \\
\text { microphylla Welw. ex Oliv., } \\
\text { Olacaceae }\end{array}$} & \multirow[t]{2}{*}{ Roots } & $\begin{array}{l}\text { Mixed with roots of } Z \text {. mucronata and boiled for } 10 \\
\text { minutes and extract used as mouth wash thrice a day }\end{array}$ & Oral cancer & 3.3 \\
\hline & & Chewed as raw thrice a day & $\begin{array}{c}\text { Teeth } \\
\text { sensitivity }\end{array}$ & 13.3 \\
\hline \multirow[t]{2}{*}{ *Jatropha curcas L., Euphorbiaceae } & \multirow[t]{2}{*}{ Rhizome } & \multirow[t]{2}{*}{$\begin{array}{l}\text { Crushed and made in to paste and applied to painful } \\
\text { teeth and gums thrice a day }\end{array}$} & $\begin{array}{l}\text { Swollen } \\
\text { gums }\end{array}$ & 6.6 \\
\hline & & & Toothache & 3.3 \\
\hline $\begin{array}{l}\text { Capparis tomentosa Lam., } \\
\text { Brassicaceae }\end{array}$ & Roots & $\begin{array}{l}\text { Boiled for } 11 \text { minutes and extract used as mouth wash } \\
\text { thrice a day }\end{array}$ & $\begin{array}{l}\text { Dental } \\
\text { caries }\end{array}$ & 3.3 \\
\hline "Citrus limon (L.) Burm.f., Rutaceae & Leaves & $\begin{array}{c}\text { Mixed with leaves of } A \text {. afra and } L \text {. javanica and boiled } \\
\text { for } 4-8 \text { minutes and extract used as mouth wash thrice a } \\
\text { day }\end{array}$ & Bad breath & 3.3 \\
\hline Drimia elata Jacq., Hyacinthaceae & Bulb & $\begin{array}{l}\text { Pounded and mixed with one teaspoon of potassium } \\
\text { permanganate } ® \text { and salt } \circledast \text { and applied on painful teeth }\end{array}$ & Toothache & 3.3 \\
\hline $\begin{array}{l}\text { Gymnosporia senegalensis (Lam.) } \\
\text { Loes., Celastraceae }\end{array}$ & Leaves & $\begin{array}{l}\text { Boiled for } 7 \text { minutes and extracts used as mouth wash } \\
\text { thrice a day }\end{array}$ & Bad breath & 3.3 \\
\hline $\begin{array}{l}\text { Lippia javanica (Burm.f.) Spreng., } \\
\text { Verbenaceae }\end{array}$ & Leaves & $\begin{array}{c}\text { Mixed with leaves of } A \text {. afra and "Citrus limon (L.) Burm.f. } \\
\text { and boiled for } 4-8 \text { minutes and extract used as mouth } \\
\text { wash thrice a day }\end{array}$ & Bad breath & 3.3 \\
\hline \multirow{2}{*}{$\begin{array}{l}\text { Myrothamnus flabellifolius Welw., } \\
\text { Myrothamnaceae }\end{array}$} & \multirow[t]{2}{*}{ Leaves } & \multirow{2}{*}{$\begin{array}{l}\text { Pounded and mixed with warm water and used as mouth } \\
\text { wash }\end{array}$} & Toothache & 3.3 \\
\hline & & & $\begin{array}{l}\text { Strengthens } \\
\text { teeth }\end{array}$ & 3.3 \\
\hline $\begin{array}{l}\text { "Opuntia ficus-indica (L.) Mill., } \\
\text { Cactaceae }\end{array}$ & Seeds & $\begin{array}{l}\text { Pounded and taken orally with warm water, mixture used } \\
\text { as mouth wash thrice a day }\end{array}$ & $\begin{array}{l}\text { Strengthen } \\
\text { teeth }\end{array}$ & 3.3 \\
\hline Persea americana Mill., Lauraceae & Roots & $\begin{array}{l}\text { Pounded and mixed with warm water and used as mouth } \\
\text { wash thrice a day }\end{array}$ & $\begin{array}{l}\text { Strengthens } \\
\text { teeth }\end{array}$ & 3.3 \\
\hline $\begin{array}{l}\text { "Petroselinum crispum (Mill.) Fuss, } \\
\text { Apiaceae }\end{array}$ & Leaves & Chewed thrice a day & Toothache & 3.3 \\
\hline "Psidium guajava L., Myrtaceae & Leaves & $\begin{array}{l}\text { Pounded and mixed with spirit } 囚 \text { and concoction used as } \\
\text { mouth wash thrice a day }\end{array}$ & $\begin{array}{l}\text { Dental } \\
\text { caries }\end{array}$ & 3.3 \\
\hline $\begin{array}{l}\text { "Spinacia oleracea L., } \\
\text { Amaranthanceae }\end{array}$ & Leaves & $\begin{array}{l}\text { Combined with fresh tuber of * Daucus carota subsp. } \\
\text { sativus (Hoffm.) Schubl. \& G. Martens, boiled for } 5 \\
\text { minutes and extract used as mouth wash thrice a day }\end{array}$ & $\begin{array}{l}\text { Strengthen } \\
\text { teeth }\end{array}$ & 3.3 \\
\hline “Thymus vulgaris L., Lamiaceae & Leaves & Chewed as raw and taken once a day & Toothache & 3.3 \\
\hline $\begin{array}{l}\text { Warburgia salutaris (G.Bertol.) } \\
\text { Chiov., Canellaceae }\end{array}$ & Leaves & $\begin{array}{l}\text { Pounded and mixed with herbal Colgate } ® \text { and applied on } \\
\text { the painful teeth }\end{array}$ & Toothache & 3.3 \\
\hline \multirow[t]{3}{*}{ "Zea mays L., Poaceae } & \multirow[t]{3}{*}{ Leaves } & \multirow{3}{*}{$\begin{array}{c}\text { Mixed with leaves of } Z \text {. mucronata in warm water for } 24 \\
\text { hours and decoction taken orally as mouth wash thrice a } \\
\text { day }\end{array}$} & $\begin{array}{l}\text { Dental } \\
\text { caries }\end{array}$ & 3.3 \\
\hline & & & Toothache & 3.3 \\
\hline & & & $\begin{array}{l}\text { Strengthen } \\
\text { teeth }\end{array}$ & 3.3 \\
\hline
\end{tabular}


tabacum (toothache), Punica granatum (bleeding gums), Ricinus communis (toothache), Solanum panduriforme (dental caries and toothache), Zanthoxylum capense (toothache) and Ziziphus mucronata (toothache). There is also ethnopharmacological support for some of these species, for example, $A$. afra is commonly used by other ethnic groups in South African [38], and its crude extract inhibited the growth of Actinomyces israelii, $A$. naeslundii, $A$. actinomycetemcomitans, $C$. albicans, $P$. gingivalis, $P$. intermedia and $S$. mutans at microbial inhibition concentration ranging from $1.6 \mathrm{mg} / \mathrm{mL}$ to $25 \mathrm{mg} / \mathrm{mL}$ [39]. Similarly, pharmacological evaluation conducted on $C$. sativa revealed its ability to inhibit growth of $C$. albicans and S. aureus [40]. Carpobrotus edulis is widely used against oral diseases in South Africa [41] and the popularity of the species in the study area might be due to the fact that the species is widely grown in home gardens and therefore, readily available as herbal medicine. Although $M$. longifolia is not necessarily used for bad breath therapy, the species is highly valued in the treatment of throat irritation, mouth and sore throat [42] as well as toothache [43] in Irag. Leaf extract of this species showed activities against $S$. aureus, S. mutans, L. acidophilus and C. albicans [42]. Ethnomedical applications of $N$. tabacum for toothache correlate with research findings by Ganesan [44] and Tapsoba and Deschamps [29] who reported similar uses in India and Burkina Faso, respectively. Crude extracts of $P$. granatum exhibited activities against $L$. acidophilus, S. mutans, and $S$. salivarius 45], thus supporting its traditional uses as medicinal against bleeding gums. Usage of $R$. communis as herbal medicine for toothache is widespread in South Africa $[46,47]$ and other African countries such as Zimbabwe [48]. Fagundes et al. [49] demonstrated the effectiveness of $R$. communis against $S$. mutans and $S$. aureaus, thus partly suggesting that this species might be effective against toothache. The Zulu people of Kwa-Zulu Natal province in South Africa use $S$. panduriforme to treat toothache [50], while Z. capense and $Z$. mucronata are widely used against toothache in South Africa [51] and Burkina Faso [29].

Other species mentioned by about a quarter of the participants $(23.3 \%)$ included Agave americana (toothache, $62.8 \%$, Allium sativum (toothache, 53.5\%), Vernonia natalensis (bad breath, 51.2\%), Zingiber officinale (bad breath, 44.2\%), Solanum mauritianum (dental caries, $41.9 \%$ ) and strengthen tooth, 34.9\%), Aloe vera (toothache, $27.9 \%$ ), Carica papaya (dental abscesss, 27.9\%), Acacia Senegal (dental carries,
27.9\%), Dodonaea viscosa (bad breath, 25.6\%), Securidaca longepedunculata (bad breath, 25.6\%), Euphorbia ingens (whiten tooth, 23.3\%) and Senna didymobotrya (toothache, $23.3 \%$ ). With the exclusion of $E$. ingens, S. mauritianum and $V$. natalensis which were reported in this study for the first time as herbal medicines for oral diseases, the other species namely A. Americana [52], A. sativum [53], Z. officinale [54], A. vera [55], C. papaya [29], Acacia senegal [56], $D$. viscosa [57], S. longepedunculata [29], S. didymobotrya [58] are widely used in the treatment and management of oral diseases in other countries.

\section{Plant Plant Parts Used and Herbal Preparation}

Herbs $(53.4 \%, n=23)$ and trees $(46.5 \%, n=20)$ were the primary sources of the medicinal plant species used for oral diseases in the Lepelle-Nkumpi Municipality in the Limpopo Province (Figure 2). More than half of the plant species $(60.4 \%, n=26)$ documented in this study were cultivated in home gardens and these included $A$. americana, $A$. sativum, A. vera, $A$. afra, Bidens pilosa, C. sativa, C. papaya, $C$. edulis, Citrus limon, D. viscosa, Drimia elata, Kleinia longiflora, Lippia javanica, N. tabacum, Opuntia ficusindica, Persea americana, Petroselinum crispum, Psidium guajava, $P$. granatum, $R$. communis, $S$. didymobotrya, Spinacia oleracea, Thymus vulgaris, Siphonochilus aethiopicus and Zea mays. About half of the documented species $(46.5 \%, n=20)$ are exotic to South Africa and these species included $A$. americana, A. sativum, A. vera, B. pilosa, C. sativa, C. papaya, $C$. limon, Jatropha curcas, $N$. tabacum, O. ficus-indica, $P$. americana, Petroselinum crispum, $P$. guajava, $P$. granatum, $R$. communis, $S$. didymobotrya, Solanum mauritianum, S. oleracea, Thymus vulgaris, Z. mays and Zingiber officinale.

Leaves $(51 \%)$ and roots $(28 \%)$ were preferred for medicinal preparations (Figure 2). Other plant parts used were bulbs, seeds, rhizomes, stems and tubers (Figure 2). A total of 47 recipes were documented in this study and the majority $(89.3 \%, n=42)$ were based on a single species while five (10.6\%) involved a combination of species (Table 1). Other non-plant products used in herbal preparations included colgate ${ }^{\circledR}$, salt $^{\circledR}$, potassium permanganate and spirit ${ }^{\circledR}$. The majority of herbal recipes were boiled $(44.6 \%, n=21)$, followed by chewing in raw form $(19.1 \%, n=9)$, pounding $(19.1 \%, n=9)$, maceration $(8.5 \%, n=4)$, crushing $(4.2 \%, n=2)$, burning or squeezing $(2.1 \%, n=1$, each) (Table 1). 


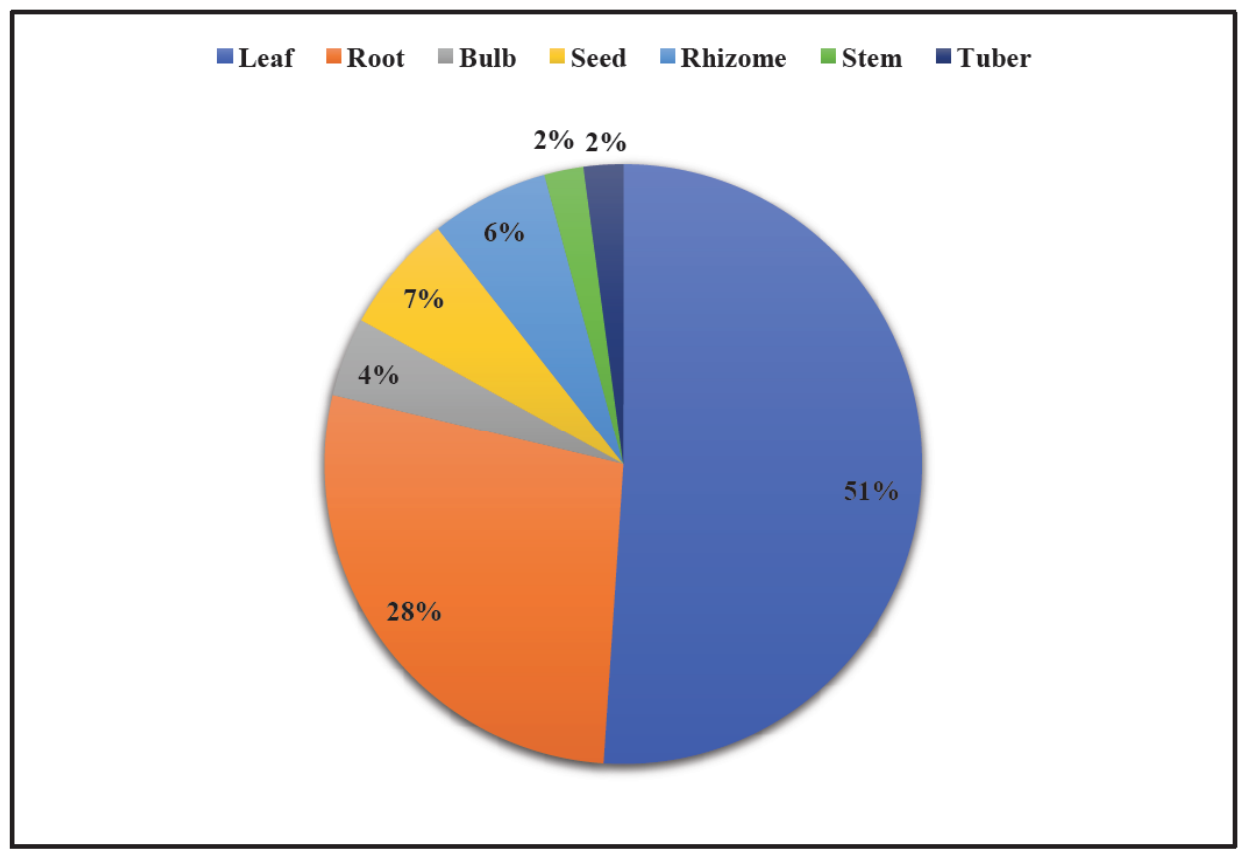

Figure 2: Plant parts used for herbal preparation.

\section{CONCLUSION}

Our survey revealed that traditional medicines plays pivotal role in the treatment of a wide spectrum of oral diseases. Hence there is a need to conduct similar studies in other areas of the Limpopo Province and South Africa at large. Some of the species documented in this study have been scientifically validated by exhibiting antibacterial and antifungal properties. Findings from the present study can be used as a basis for future phytochemical and pharmacological investigations. Therefore, these findings call for detailed ethnopharmacological studies emphasizing clinical and toxicological evaluations assess efficacy and safety of such species as herbal medicines against oral infections.

\section{ACKNOWLEDGEMENTS}

The authors are grateful to the traditional healers practising in the Lepelle-Nkumpi Municipality for participating in this study and sharing their valuable knowledge on medicinal plants used against oral diseases. This study was possible through a grant provided by National Research Foundation (NRF) and Govan Mbeki Research and Development Centre (GMRDC), University of Fort Hare with grant number T398 and C169, respectively.

\section{REFERENCES}

[1] World Health Organisation (WHO), Promoting oral health in Africa: prevention and control of oral diseases and noma as part of essential noncommunicable disease interventions.
World Health Organisation, World Health Organization. Regional Office for Africa, 2016.

[2] Marcenes W, Kassebaum NJ, et al. Global burden of oral conditions in 1990-2010: a systematic analysis. J Dent Res 2013; 92: 592-597.

https://doi.org/10.1177/0022034513490168

[3] Abid A, Maatouk F, et al. Prevalence and severity of oral diseases in the Africa and Middle East Region. Adv Dent Res 2015; 27: 10-17. https://doi.org/10.1177/0022034515582062

[4] Thema LK, Singh S. Integrated primary oral health services in South Africa: the role of the PHC nurse in providing oral health examination and education. Afr J Pr Health Care Fam Med 2013; 5(1): Art. \#413.

[5] Braine $T$, More oral health care needed for ageing populations. Bull World Health Organ 2005; 83: 646-647.

[6] Thorpe S, Oral health issues in the African region: current situation and future perspectives. J Dental Ed 2006; 70: 8-15.

[7] Akpata ES, Oral health in Nigeria. Int Dental J 2004; 54: 361 366. https://doi.org/10.1111/j.1875-595X.2004.tb00012.x

[8] Umoh AO, Azodo CC, Prevalence of gingivitis and periodontitis in an adult male population in Nigeria. Nigeria $J$ Basic Clin Sci 2012; 9: 65-69. https://doi.org/10.4103/0331-8540.108465

[9] Muwazi LM, Rwenyonyi CM, et al. 2005. Prevalence of oral diseases/conditions in Uganda. Afr Health Sci 2005; 5: 227233.

[10] Ministry of Health and Social Services, National oral health survey Namibia 2010/11. Republic of Namibia, Windhoek, 2013.

[11] Ministry of Health, Kenya national oral health survey report 2015. Ministry of Health, Kenya, Nairobi, 2015.

[12] Matee MI, Scheutz F, Moshy J, Occurrence of oral lesions in relation to clinical and immunological status among HIVinfected adult Tanzanians. Oral Dis 2000; 6: 106-111. https://doi.org/10.1111/j.1601-0825.2000.tb00110.x

[13] Singh S, Dental caries rates in South Africa: implications for oral health planning. South Afr J Epidemiol Infect 2011; 26 : 259-261. https://doi.org/10.1080/10158782.2011.11441463 
[14] Mokhine IMN, Oral health status of special olympics athletes in four provinces of South Africa. MSc dissertation, University of the Witwatersrand, Johannesburg 2015.

[15] Van Wyk B-E, Wink M, Medicinal plants of the world. Briza Publications, Pretoria, 2004.

[16] Petersen PE, The world oral health report 2003: continuous improvement of oral health in the 21st century: the approach of the WHO global oral health programme. Comm Dentistry Oral Epid 2003; 31(1): 3-24. https://doi.org/10.1046/j..2003.com122.x

[17] Henley-Smith CJ, Botha FS, et al. The use of plants against oral pathogens. In: Mendez-Vilas A (Ed.), Microbial pathogens and strategies for combating theme: science, technology and education, FORMATEX, Extremadura, Spain 2013; pp. 1375-1384.

[18] Wanja FW, Safety and antimicrobial activities of herbal materials used in management of oral health by traditional medical practitioners in Nairobi County, Kenya. PhD thesis, Kenyatta university, Nairobi 2013.

[19] Zarco MF, Vess TJ, et al. The oral microbiome in health and disease and the potential impact on personalized dental medicine. Oral Dis 2012; 18(2): 109-120.

https://doi.org/10.1111/j.1601-0825.2011.01851.x

[20] Oral Health Atlas, The challenge of oral disease: a call for global action. FDI, Geneva 2015. https://www.fdiworlddental.org/resources/oral-healthatlas/oral-health-atlas-2015. [Accessed 9 December 2018].

[21] Enwanwu CO, Anyanwu RC, The chewing stick in oral health care. World Health Forum 1985; 6: 232-234.

[22] Yadav R, Yadav SK, Dental disease and its cure: a review. Asian J Pharmaceut Clinical Res 1985; 6: 16-20.

[23] Borhan-Mojabi K, Azimi S, Antimicrobial natural products in oral health. In: Mendez-Vilas A (Ed.), Microbial pathogens and strategies for combating theme: science, technology and education, FORMATEX, Extremadura, Spain 2013, pp. 13751384.

[24] Sekar K, Mrugan K, et al. Anticaries potential of ethnomedical plants used by Malayali tribals from Kolli hills, India. Indian J Trad Knowl 2016; 15: 109-115.

[25] Ngilisho LAF, Mosha HJ, et al. The role of traditional healers in the treatment of toothache in Tanga Region, Tanzania. Comm Dental Health 1994; 11: 240-242.

[26] Ogunbodede E, Dental care: the role of traditional healers. World Health Forum 1991; 12: 444-445.

[27] Lewis HA, Rudolph MJ, et al. Oral health knowledge and original practices of African traditional healers in Zonkizizwe and Dube, South Africa. South Afr Dental J 2004; 59: 243246.

[28] Sarita PT, Tuominen R, Use of health care services in two rural communities in Tanzania. Comm Dentistry Oral Epid 1993; 21(3): 133-135.

https://doi.org/10.1111/j.1600-0528.1993.tb00737.x

[29] Tapsoba H, Deschamps JP, Use of medicinal plants for the treatment of oral diseases in Burkina Faso. J Ethnopharmacol 2006; 104: 68-78. https://doi.org/10.1016/j.jep.2005.08.047

[30] Idu M, Umweni AA, et al. Ethnobotanical plants used for oral healthcare among the Esan tribe of Edo State, Nigeria. Ethnobot. Leaflets 2009; 13: 548-563.

[31] Agbor AM, Naidoo $S$, et al. The role of traditional healers in tooth extractions in Lekie division, Cameroon. J Ethnobiol Ethnomed 2011; 7: 15. https://doi.org/10.1186/1746-4269-7-15

[32] Agbor MA, Naidoo S, Ethnomedicinal plants used by traditional healers to treat oral health problems in Cameroon. Evidence-Based Complem. Altern. Med. Volume 2015, Article ID 649832.

[33] Lepelle-Nkumpi Local Municipality, 2016-2021. Integrated development plan: 2016-2021. Lepelle-Nkumpi Municipality,
Lebowakgomo. http://www.lepelle-nkumpi.gov.za/lepellenkumpi-admin/pages/sites/lepellenkumpi/documents/idp/ LNM\%20INTEGRATED\%20DEVELOPMENT\%20PLAN\%20 2016-2021.pdf. [Accessed 17 October 2018].

[34] Mucina L, Rutherford MC, The vegetation of South Africa Lesotho and Swaziland. South African National Biodiversity Institute, Pretoria 2006.

[35] South African Weather Service (SAWS), South African rainfall data 2012. http://www.weathersa.co.za. [Accessed 10 September 2018].

[36] Statistic South Africa, Demographic profile of Lepelle-Nkumpi Municipality. Statistic South Africa, Pretoria 2011.

[37] Ocheng F, Ugandan medicinal plants used traditionally for oral care: Investigation of extracts for anti-bacterial, cytotoxic and anti-inflammatory effects. $\mathrm{PhD}$ thesis, Makerere University, Kampala 2015.

[38] Van Wyk B-E, Gericke N, People's plants: a guide to useful plants of southern Africa. Briza Publications, Pretoria 2007.

[39] More G, Lall N, et al. Antimicrobial constituents of Artemisia afra Jacq. ex Willd. against periodontal pathogens. EvidenceBased Complem. Altern. Med. Volume 2012, Article ID 252758.

[40] Ali EMM, Almagboul AZI, et al. Antimicrobial activity of Cannabis sativa L. Chinese Med 2012; 3: 61-64. https://doi.org/10.4236/cm.2012.31010

[41] Van Wyk B-E, Van Oudtshoorn B, et al. Medicinal plants of South Africa. Briza Publications, Pretoria 2013.

[42] Al-Bayati FA, Isolation and identification of antimicrobial compound from Mentha longifolia L. leaves grown wild in Iraq. Ann Clin Microbiol Antimicrob 2009; 8: 20-28. https://doi.org/10.1186/1476-0711-8-20

[43] Naghibi F, Mosaddegh $M$, et al. Labiatae family in folk medicine in Iran: from ethnobotany to pharmacology. Iran J Pharm Res 2005; 4: 63-79.

[44] Ganesan S, Traditional oral care medicinal plants survey of Tamil Nadu. Nat Prod Radiant 2008; 7: 166-172.

[45] Howell AB, D'Souza HD, The pomegranate: effects on bacteria and viruses that influence human health. EvidenceBased Complem. Altern. Med. Volume 2013, Article ID 606212.

[46] Watt JM, Breyer-Brandwijk MG, The medicinal and poisonous plants of southern and eastern Africa. E. \& S. Livingstone, London 1962.

[47] Mabogo DEN, The ethnobotany of the VhaVenda. MSc dissertation. University of Pretoria, Pretoria 1990.

[48] Gelfand $M$, Drummond RB, et al. The traditional medical practitioner in Zimbabwe: his principles of practice and pharmacopoeia. Mambo Press, Gweru 1985.

[49] Fagundes LVN, Barchelli PJ, et al. In vitro antimicrobial activity of an experimental dentifrice based on Ricinus communis. Braz Dent J 2017; 25(3): 191-196.

[50] Hutchings $\mathrm{A}$, Scott $\mathrm{AH}$, et al. Zulu medicinal plants: an inventory. University of Natal Press, Pietermaritzburg 1996.

[51] Steyn P, Van Den Heerver J, et al. Biologically active substances from Zanthoxylum capense (Thunb.) Harv. S Afr J Sci 1998; 94: 391-393.

[52] Keith C, Agave americana: Agave 2002. http://entheology. com/plants/agave-americana-agave/. [Accessed on 4 December 2018].

[53] Bayan L, Koulivand PH, et al. Garlic: a review of potential therapeutic effects. Avicenna J Phytomed 2014; 4(1): 1-14. https://www.ncbi.nlm.nih.gov/pmc/articles/PMC4103721/.

[54] The Herbal Resource, Herbal remedies for halitosis (bad breath) $2017 . \quad$ https://www.herbal-supplementresource.com/halitosis-herbs-remedies.html. [Accessed on 5 December 2018].

[55] Intelligent Dental, The best home remedy for toothache pain 2017. http://www. intelligentdental.com/2011/01/20/the-best- 
home-remedy-for-toothache-pain/. [Accessed on 9 December 2018].

[56] Natural Remedies Center, Acacia senegal gum for cough, ulcers and wounds: arabic and African remedies 2017. http://www.naturalremediescenter.com/4780/acacia-senegalgum-for-cough-ulcers-wounds-arabic-african-remedies/. [Accessed on 7 December 2018].
[57]

Palmer E, Pitman P, Trees for southern Africa covering all known indigenous species in Republic of South Africa, South West Africa, Botswana, Lesotho and Swaziland. A.A. Balkema, Cape Town 1972.

[58] Ngari FW, Wanjau RN, et al. Herbal materials used in management of oral conditions in Nairobi, Kenya. J Oral Health Comm Dent 2014; 8: 36-42. 